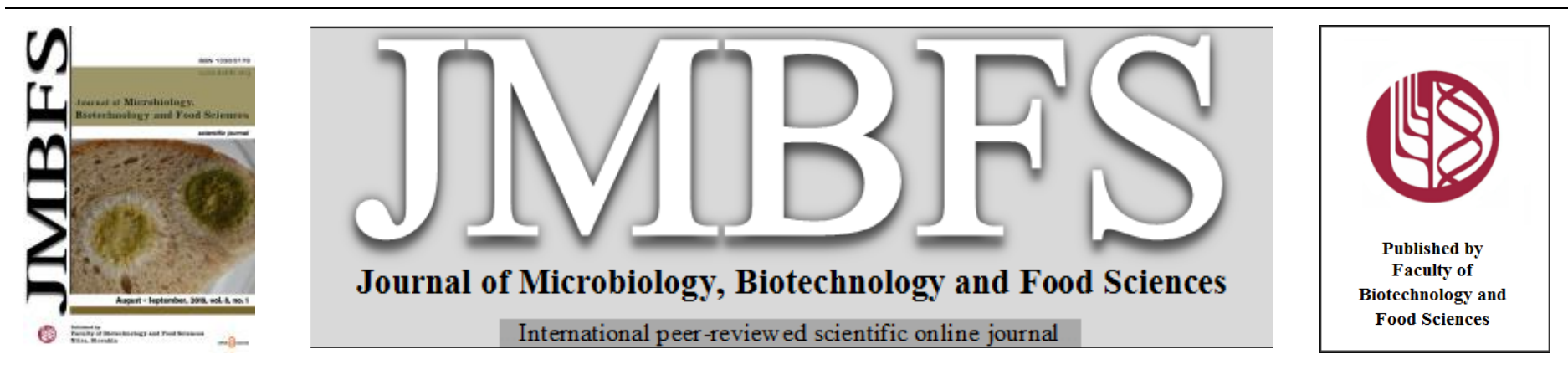

\title{
A COMPARATIVE ASSESSMENT OF SEMEN QUALITY IN SMOKERS AND NON-SMOKERS INCLUDING SPERM BPDE-DNA ADDUCT FORMATION AND ACROSOME STATUS
}

\author{
Rinku Saha ${ }^{1}$, Shubhadeep Roychoudhury ${ }^{1}$, Kushal Kumar Kar ${ }^{2}$, Alex C. Varghese ${ }^{3}$, Parag Nandi ${ }^{4}$, Sreyashi Mitra ${ }^{5}$, Nabendu Murmu $^{5}$, \\ Peter Massanyi ${ }^{6}$ and Adriana Kolesarova ${ }^{6}$
}

Address(es):

${ }_{1}^{1}$ Department of Life Science and Bioinformatics, Assam University, Silchar, India.

${ }^{2}$ Mediland Fertility Clinic, Mediland Hospital and Research Centre, Silchar, India.

${ }^{3}$ Astra Fertility Group, Mississagua, Ontario, Canada.

${ }^{4}$ Department of Environmental Science, University of Calcutta, India.

${ }^{5}$ Chittaranjan National Cancer Institute, Kolkata, India.

${ }^{6}$ Department of Animal Physiology, Faculty of Biotechnology and Food Sciences, Slovak University of Agriculture in Nitra, Slovak Republic.

*Corresponding author: shubhadeep1@gmail.com

doi: 10.15414/jmbfs.2018.8.1.741-744

ARTICLE INFO

Received 3. 5. 2018

Revised 21. 6. 2018

Accepted 18. 7. 2018

Published 1. 8. 2018

Regular article

OPEN $\partial_{\text {ACCESS }}$

\section{ABSTRACT}

The objective of the present study was to investigate semen quality of infertile smokers and non-smokers including Benzo[ $[a]$ Pyrene-7,8diol-9,10 epoxide (BPDE)-DNA adduct formation and acrosome status of sperm cells. Semen quality parameters were analyzed according to 2010 World Health Organization criteria in 122 non-smokers and 125 cigarette smokers attending tertiary health care centre in Barak Valley of Assam, India followed by BPDE-DNA adduct formation and acrosome status test. A significant decline was found in sperm concentration, progressive motility, morphology in smokers $(p<0.05)$ in comparison to non-smokers. However, no significant difference was noted between the two groups of infertile men in terms of macroscopic parameters of semen quality, such as semen appearance, volume, liquefaction and $\mathrm{pH}$, as well as sperm vitality. Formation of BPDE-DNA adducts was visible in smokers whereas acrosomal intactness was evident in non-smokers. These findings corroborate the affect of smoking on semen quality indicating its involvement in the pathophysiology of male factor infertility.

Keywords: Male infertility, tobacco, cigarette, smoking, semen quality, sperm

\section{INTRODUCTION}

Infertility, or the inability to conceive children after one year of unprotected intercourse, affects $10-15 \%$ of couples, who are trying to conceive (Rowe et al., 2000). Infertility affects both men and women of reproductive age and male factor attributes to $50 \%$ of the infertility cases (Dohle et al., 2005). Male infertility is rising at a faster rate keeping pace parallel to emerging new technologies. Rapid urbanization and industrialization has lead to drastic changes in the lifestyle of people. Among these factors, tobacco smoking is the most widespread hazardous lifestyle predominant in men of reproductive age (Trummer et al., 2002). A large number of men have no apparent reason for their infertility and are habituated to smoking tobacco unaware of the fact that their reproductive potency is adversely affected (Oliva et al., 2001; Homan et al., 2007). Several studies reported that smoking habit may be linked to the prevalence of male infertility worldwide (Ferreira et al., 2012; Arabi and Mosthanghi, 2005).

Tobacco is a green, leafy plant grown in tropical and sub-tropical countries. The dried ground leaves of this plant are either smoked in the form of cigar, cigarette, pipe or can be used in smokeless form by chewing gutka, khaini, zarda, etc., smoking being the most common type of tobacco use. Tobacco combustion yields about 4000 different compounds and out of these, more than 55 of them are known carcinogens and about 400 are toxic chemicals (Kumar et al., 2011) Tobacco smoke comprises of two phases - gaseous phase containing poisonous gases, vaporised liquids and particulate phase in the form of minute droplets. The major constituents of gaseous fraction are carbon monoxide, nitrogen oxide, ammonia and hydrocarbons (Matikainen et al., 2001) whereas, the particulate phase is mainly composed of aggregates of nicotine (Matikainen et al., 2001; Inyang et al., 2003), cotinine, benzopyrene etc. which are beleived to have profound impact on male reproductive health, declining semen parameters and sperm function (Hammond et al., 2006).

Benzopyrene $[a]$ Pyrene $(\mathrm{B}[a] \mathrm{P})$, a byproduct of incomplete combustion of organic compounds such as gasolene, cigarette, wood, etc., is a polycyclic aromatic hydrocarbon which is metabolized in human body into various toxic forms (Revel et al., 2001). These metabolites bind with DNA forming a structure called Benzo[ $a]$ Pyrene-7,8-diol-9,10 epoxide (BPDE) which binds covalently with DNA forming BPDE-DNA adduct that has the capability to interfere with or alter DNA replication (Sipinen et al., 2010). At concentration higher than $25 \mu \mathrm{g} / \mathrm{ml}$ benzo[ $a]$ pyrene can induce premature capacitation and false acrosome reaction in sperm cells in vitro (Mukhapadhyay et al., 2009).

In India, since last decade tobacco smoking in the form of cigarette has increased manifold. A survey conducted on the prevalence of tobacco smoking revealed substantial increase in the number of male smokers aged 15-69 years accounting to nearly 108 million in 2015 (Misra et al., 2016). In north eastern part of India including Assam, Ttbacco in both smoking and non-smoking form is widely prevalent among diverse ethnic tribes as well as other communities irrespective of age groups. Due to the increasing incidence of decline in male fertility and high prevalence of tobacco use among the youths, an effort has been made to investigate the effect of cigarette smoking on semen quality of infertile men in Barak Valley of Assam in India mainly belonging to two groups - cigarette smokers and non-smokers.

\section{MATERIALS AND METHODS}

\section{Study Group}

The study was carried out at Assam University, Silchar. A total of 376 men of reproductive age attending tertiary healthcare centre for routine infertility problems were randomly selected for the study. The study was approved by the Institutional Ethical Committee and each subject signed an informed consent including completing a comprehensive questionnaire concerning name, age, duration of conjugal life, socio-economic condition, lifestyle behaviour such as consumption of tobacco, alcohol, certain illicit drugs, exposure to radiation, pesticides or heavy metals etc.

Information on smoking behaviour included number of cigarettes per day, years of smoking, etc. Infertile subjects smoking at least 1 to $>20$ cigarettes per day were categorized as active smokers and such men who did not smoke nor 
exposed to smoke in their work place were categorized as non-smokers. Subjects who were suffering from diabetes or other diseases, and/or under medication for more than a week were excluded from the study group.

\section{Semen Analysis}

Analysis of the semen samples were performed according to 2010 World Health Organization criteria (WHO, 2010). Each subject was instructed for sexua abstinence for at least 2 days before producing the semen by masturbation into a wide-mouthed sterile container labelled with the name of the subject, date and time of collection. The collected semen samples were kept at an incubator at $37^{\circ} \mathrm{C}$ for liquefaction followed by semen analysis which includes macroscopic evaluation of semen parameters such as semen appearance volume, viscosity, $\mathrm{pH}$ liquefaction time, and microscopic evaluation that includes concentration, progressive motility, morphology, and vitality of sperm cells (Roychoudhury et al., 2016; 2017). Microscopic observation was carried out under appropriate magnification using phase contrast microscope (Labomed-LX 300).

\section{BPDE-DNA Adduct Formation}

Detection of BPDE-DNA adducts formation was performed by immunostaining method with modification of the process as reported earlier (Zenzes et al., 1999

Ji et al., 2013). Sperm cells were washed in $10 \mathrm{mmol} / \mathrm{L}$ Tris buffer followed by washing again with phosphate buffered saline (PBS) solution. The washed sample was spread onto one clean glass slide; air dried and fixed with methanol acetic acid $(3: 1)$ overnight at $-20^{\circ} \mathrm{C}$. Before staining, the slides were washed with PBS treated with RNase $\left(100 \mu \mathrm{g} / \mathrm{mL}\right.$ for 1 hour at $\left.37^{\circ} \mathrm{C}\right)$. The slides were again treated with proteinase $\mathrm{K}(10 \mu \mathrm{g} / \mathrm{mL}$ for $10 \mathrm{~min})$ and washed again with $\mathrm{PBS}$, incubated in $4 \mathrm{~N} \mathrm{HCl}$ for 10 minutes, neutralized with $50 \mathrm{mmol} / \mathrm{L}$ Tris-base for 5 minutes, and washed with PBS. Those were again incubated with $10 \%$ goa serum for 45 minutes at $37^{\circ} \mathrm{C}$ followed by overnight incubation at $4{ }^{\circ} \mathrm{C}$ with a mouse monoclonal primary antibody against BPDE-DNA that had been diluted 1:50 in blocking solution $(5 \%$ goat serum in $10 \mathrm{mmol} / \mathrm{L}$ Trisbuffer, $0.1 \%$ Triton $\mathrm{X}-100)$. After washing with PBS, the slides were incubated for 45 minutes at $37^{\circ} \mathrm{C}$ with a secondary Alexa Fluor 488 goat antimouse IgG antibody at a dilution of 1:200. The sperm cells with BPDE-DNA adduct emitted green fluorescence.

\section{Acrosome Status}

In order to examine if $\mathrm{B}[a] \mathrm{P}$ induce false acrosomal reaction, the acrosomal halo test in sperm cells was performed according the method as described by Saxena et al. (2008) and Muhkhapadhaya et al., (2010). Semen samples were diluted in PBS:D-glucose $(1: 20)$ and equilibrated at $37^{\circ} \mathrm{C}$ for 30 minutes. $20 \mu 1$ of diluted mixture was gently smeared on gelatine coated slide and excess water was evaporated. The slides were then incubated in a humid chamber at $37^{\circ} \mathrm{C}$ for 120 minutes, air-dried and examined under the microscope to evaluate the percentage of spermatozoa with halos surrounding their heads.

Statistical Analysis

Data recorded in questionnaire and semen analysis report were introduced in an Excel database. Statistical analysis was done using statistical software package SPSS (version 7). Descriptive analysis was presented as Mean \pm Standard Deviation (SD). Analysis of variance was performed using one-way ANOVA and reported as significant when $p<0.05$.

\section{RESULTS AND DISCUSSION}

Men and women of reproductive age are highly fascinated towards smoking habit (Trummer et al., 2002). Prenatal maternal exposure to tobacco smoke is one of the most potent predictor of poor semen quality than in adult smokers (Jensen et al. (2004). Tobacco smoking is a huge health threat the world has been facing (WHO, 2013) which is ruthlessly affecting fecundity (Ramlau Hansen et al. 2006). Tobacco smoke is also known to disrupt the hypothalamic-pituitarygonadal axis thereby causing inconsistency in testicular hormones and decline in fertility potential among smokers (Ramlau Hansen et al., 2008).

In this study, a comparative analysis of semen quality among 247 infertile men of reproductive age was carried out with an intention to elucidate the impact of tobacco smoking habit on semen quality. The subjects were categorized into two groups: non-smokers $(n=122)$, and smokers $(n=125)$. The results indicate that tobacco has profound impact on semen quality, and thus male fertility.

No significant difference $(p>0.05)$ was noted between the groups of non-smokers and smokers in terms of macroscopic parameters of semen quality such as appearance, volume $(2.50 \pm 1.17 \mathrm{ml}$ versus $2.45 \pm 1.28 \mathrm{ml}), \mathrm{pH}(7.76 \pm 0.81$ versus $7.73 \pm 0.57)$ and liquefaction time $(26.19 \pm 17.2$ min versus $27.65 \pm 17.7$ min). Microscopic parameters of semen quality such as sperm concentration, motility, progressive motility, morphology, and vitality are of paramoun importance to the sperm cell as they ensure capacitation, hyperactivation and subsequent fertilization. In the infertile men under study, a significant decrease was noted in the following semen quality parameters $(\mathrm{p}<0.05)$ in smokers in comparison to non-smokers: sperm concentration $\left(107.6 \pm 82.3 \times 10^{6} / \mathrm{ml}\right.$ in non- smokers versus $84 \pm 79.6 \times 10^{6} / \mathrm{ml}$ in smokers), progressive motility (55.55 \pm $54.07 \%$ in non-smokers versus $36.98 \pm 38.60 \%$ in smokers $)$, morphology $(6.20 \pm$ $5.24 \%$ in non-smokers versus $4.84 \pm 4.20 \%$ in smokers) [Figure 1 (a) \& (b)], vitality $(56.98 \pm 20.99 \%$ in non-smokers versus $54.37 \pm 23.80 \%$ in smokers $)$ [Figure 2 (a) \& (b)].

Benzo $[a]$ Pyrene, which is the one of the main constituent of smoke resulting from automobile exhaust, combustion of tobacco, coal tar, etc. acts as mutagen as well as carcinogen (Revel et al., 2001). Tobacco smoking elevates BPDE-DNA adduct formation (Mukhopadhyay et al., 2010). Studies suggest that exposure to $\mathrm{B}[a] \mathrm{P}$ might be correlated with poor semen quality and increased risk of infertility (Zenzes et al., 1999). In order to further validate our study on the consequences of smoking on semen quality of infertile smoking subjects $\mathrm{B}[a] \mathrm{P}$ adducts

formation were investigated. Semen samples were randomly selected for the assessment of BPDE-DNA adducts formation. The results of our experiment exhibited Moderate adduct formation was also noted in non-smokers with sparingly stained sperm cells, which might be due to environmental exposure to $\mathrm{B}[a] \mathrm{P}$ that is abundant in the atmosphere [Figure 3 (a), (b) \& (c)]. Highly stained sperm cells in smokers pointed towards severe adduct formation [Figure 3 (d) \& (e)].

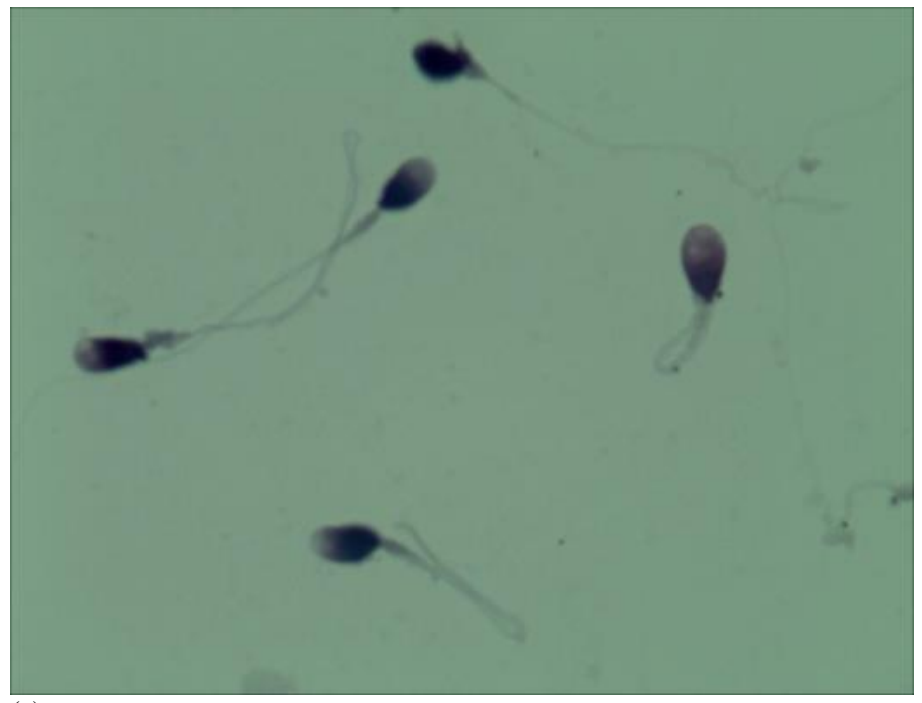

(a)

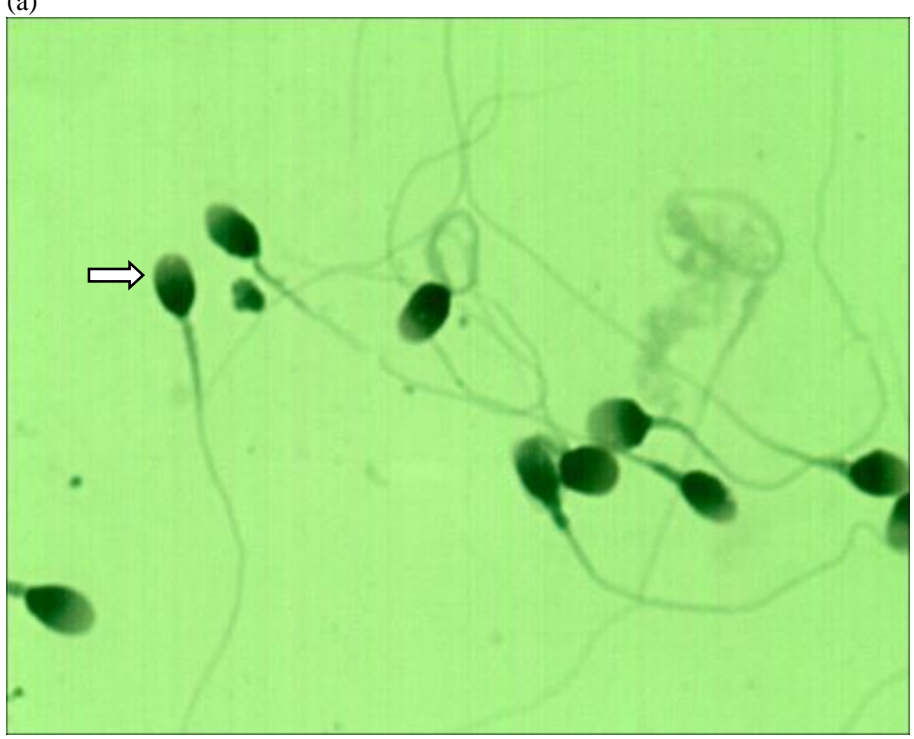

(b)

Figure 1 Sperm morphology of in infertile men: (a) sperm cells with multiple abnormalities in smokers; (b) few normal spermatozoa among non-smokers as indicated by arrow. 

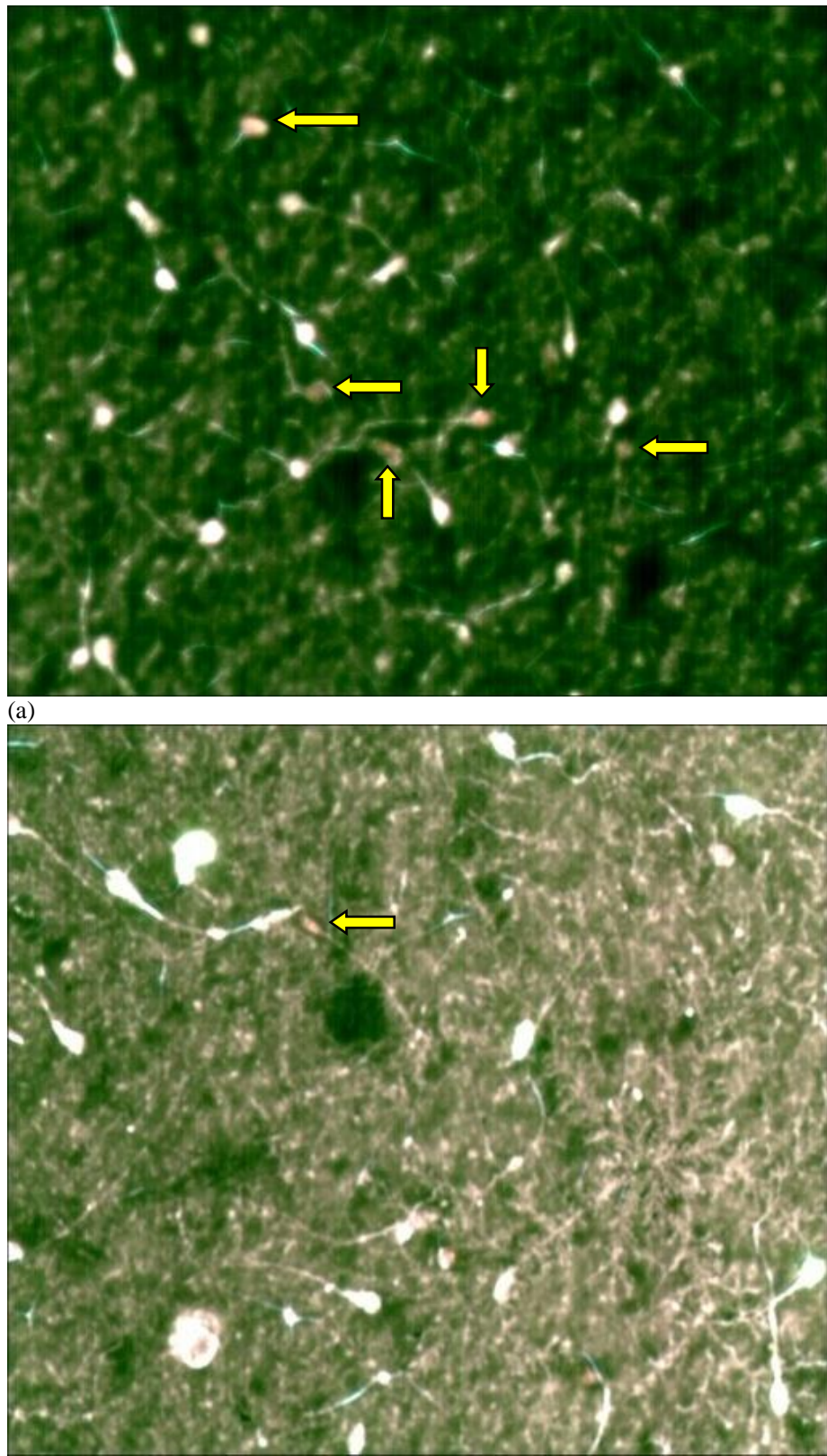

(b)

Figure 2 Sperm vitality in infertile men: (a) large numbers of non-viable spermatozoa in smokers; (b) few non-viable spermatozoa in non-smokers as indicated by arrow.

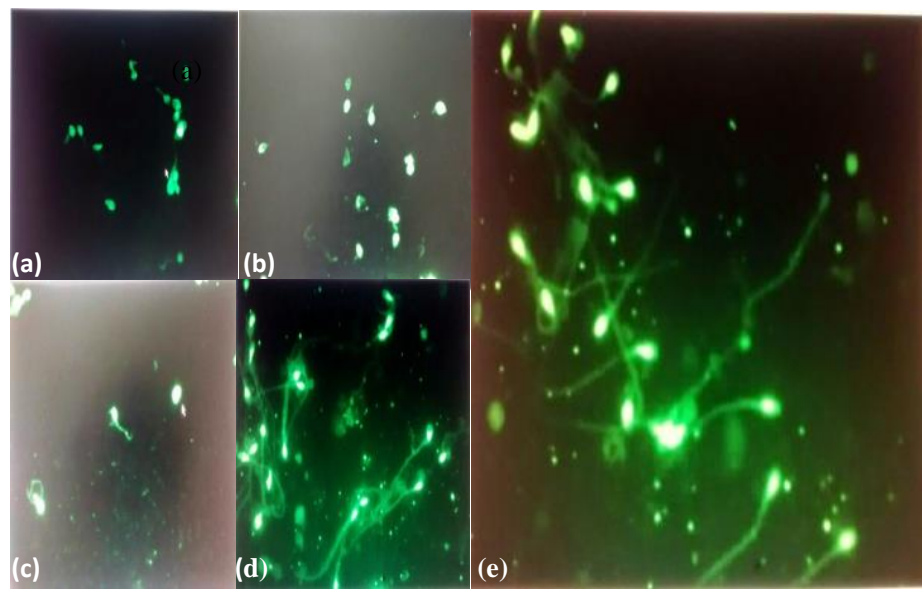

Figure 3 Formation of BPDE-DNA adducts in sperm cells of infertile men (a), (b) and (c) showing mild adduct formation in non-smokers; (c) and (d) showing highly stained sperm cells that indicate high adduct formation in smokers.

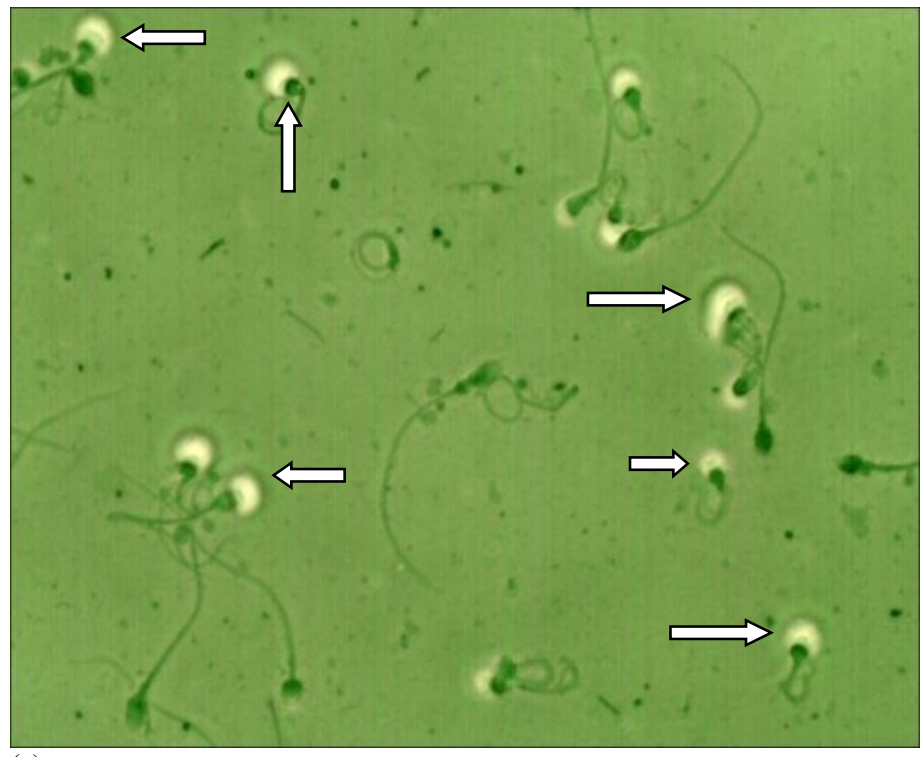

(a)
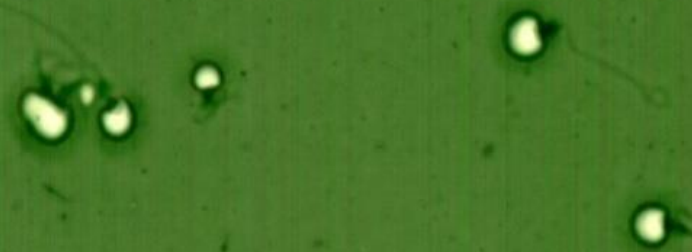

(b)

Figure 4 Acrosomal intactness of sperm cells in infertile men: (a) intact acrosome with halo formation around most of the sperm heads in non-smokers; (b) halo formation in few sperm cells as indicated by arrows suggesting acrosome reaction in smokers.

Benzo(a)pyrene is also believed to affect sperm function and capacitation by inducing hyperactivation and false acrosome reaction (Mostafa, 2010). $\mathrm{B}[a] \mathrm{p}$ is known to elevate the intracellular $\mathrm{Ca}^{2+}$ and tyrosine phosphorylation activity that induces flagellar $\mathrm{Ca}^{2+}$ resulting in hyperactivation of spermatozoa. Hence, the B(a)P induced hyperactivated sperm cells exhaust their acrosomal enzymes and fail to fertilize (Mukhopadhyay et al., 2010). Our experiment conducted with gelatine-based acrosomal halo test confirmed more acrosomal intactness in sperm cells non-smokers [Figure 4(a)] than that of smokers [Figure 4(b)].

\section{CONCLUSIONS}

Although literature report the adverse impact of cigarette smoking on semen quality but only few demonstrate direct negative effect on sperm concentration, progressive motility and morphology. The findings of the present study substantiate the effect of tobacco smoking on semen quality vis-a-vis male fertility. Severe BPDE-DNA adducts formation in sperm cells of infertile smokers as well as alteration of acrosome status in such men corroborate the involvement of cigarette smoking in the pathophysiology of male factor infertility.

Acknowledgements: This work has been supported by the Department of Biotechnology, Government of India grant release no. BT/265/NE/TBP/2011 and Assam University, Silchar, India.

\section{REFERENCES}

Arabi M. \& Mosthaghi H. (2005). Influence of cigarette smoking on spermatozoa via seminal plasma. Andrologia, 37(4), 119-124. http://doi.org/101111/j.1439$\underline{0272.2005 .00664 . \mathrm{x}}$ 
Arabi M. (2004). Nicotinic infertility: assessing DNA and plasma membrane integrity of human spermatozoa. Andrologia, 36(5), 305-310. https://doi.org/10.1111/j.1439-0272.2004.00623.x

Bernard A. (2008). Cadmium \& its effect on human health. Indian Journal of Medicinal Research, 128(4), 557-564.

Collodel G., Capitani S., Pammolli A., Giannerini V., Geminiani M. \& Moretti E. (2010) Semen quality of male idiopathic infertile smokers and non-smokers: an ultrastructural study. Journal of Andrology, 31(2): 108-113. https://doi.org/10.2164/janrol.109.007773

Dohle GR., Colpi GM., Hargreave TB., Papp GK., Jungwirth A. \& Weodner W. (2005). EAU guidelines on male infertility. European Urology, 48, 703-711. https://doi.org/10.1016/j.eururo.2005.06.002

Ferreira M., Silva JV., Silva V., Barros A., da Cruz e Silva OAB. \& Fardilha M. (2012). Lifestyle influences human sperm functional quality. Asian Specific Journal of Reproduction, 1(3), 224-230. https://doi.org/10.1016/S2305$\underline{0500(13) 60081-0}$

Hammond D., Fong GT., Cummings KM., O'Connor RJ., Giovino GA. \& McNeill A. (2006). Cigarette yields and human exposure: a comparison of alternative testing regimens. Cancer Epidemiology, Biomarkers and Prevention, 15(8), 1495-1501. doi:10.1158/1055-9965.EPI-06-0047

Homan GF., Davies M. \& Norman R. (2007). The impact of lifestyle factors on reproductive performance in the general population and those undergoing infertility treatments: a review. Human Reproduction Update, 13(3), 209-233. https://doi.org/10.1093/humupd/dml056

Inyang F., Ramesh A., Kopsombut P., Niaz MS., Hood DB., Nyanda AM. \& Archibong AE. (2003). Disruption of testicular steroidogenesis and epididymal function by inhaled benzo(a)pyrene. Reproductive Toxicology, 17(5), 527-537. https://doi.org/10.1016/S0890-6238(03)00071-6

Jensen TK., Jorgensen N., Punab M., Haugen TB., Souminen J., Zilaitiene B., Horte A., Andersen AG., Carlsen E, Magnus O., Matulevicius V., Nermoen I.,Vierula M., Keiding N., Toppari J. \& Skakkebaek NE. (2004). Association of in utero exposure to maternal smoking with reduced semen quality and testis size in adulthood: a cross-sectional study of 1,770 young men from the genera population in five European countries. American Journal of Epidemiology, 159(1), 49-58. https://doi.org/10.1093/aje/kwh002

Ji G., Yan L., Wu S., Liu J., Wang L., Zhang S., Shi L. \& Gu A. (2013). Bulky DNA adducts in human sperm associated with semen parameters and sperm DNA sectional study. Environmental Health, 12(1), 82 .

Joo KJ., Kwon YW., Myung SC. \& Kim TH. (2012).The effect of smoking and alcohol intake on sperm quality: Light and transmission electron microscopy findings. Journal of International Medical Research, 40(6), 2327-2335. doi:10.1177/030006051204000631

Kumar A., Pant MC. \& Khandelwal S. (2011). Role of OGGI Ser326Cys polymorphism and 8-oxoguanine DNA damage in risk assessment of squamous cell carcinoma of head and neck in North Indian population. Mutation Research, 726(2), 227-233. https://doi.org/10.1016/j.mrgentox.201109.015

Kunzle R., Mueller MD., Hanggi W., Birkhauser MH., Drescher H. \& Bersinge NA. (2003). Semen quality of male smokers and non smokers in infertile couples Fertility and Sterility, 79(2), 287-291. https://doi.org/10.1016/S0015 0282(02)04664-2

Martini AC., Estofan D., Senestrari D., de Cuneo MF. \& Ruiz RD. (2004) Effects of alcohol and cigarette consumption on human seminal quality. Fertility and Sterility, 82(2), 374-377. doi:10.1016/j.fertnstert.2004.03.022

Massanyi P., Lukac N., Stawarz R., Roychoudhury S., Slamecka, J., Chlebec I., Toman R., Kovacik J. \& Bulla J. (2009). Environmental concentration of cadmium in rabbit semen and detection of the effect on spermatozoa motility in vitro. World Applied Sciences Journal, 5(Special Issue for Environment), 21-31.

Misra S., Joseph RA., Gupta CP., Pezzack B., Ram F., Sinha DN., Dikshit R., Patra J. \& Jha P. (2016). Trends in bidi and cigarette smoking in India from 1998 to 2015, by agr, gender and education. BMJ Global Health, 1(1), e00005 doi:10.1136/bmjgh-2015-000005

Mostafa T. (2010). Cigarette smoking and male fertility. Journal of Advanced Research, 1,179-186. https://doi.org/10.1016/j.jare.2010.05.002

Mukhopadhyay D., Nandi P., Varghese AC., Gutgutia R., Banerjee S. and Bhattacharyya AK. (2010). The in vitro effect of benzo[a]pyrene on human sperm hyperactivation and acrosome reaction. Fertility and Sterility, 94(2), 595598. https://doi.org.10.1016/j.fertnstert.2009.02.031

Oliva A., Spira A. \& Multigner L. (2001). Contribution of environmental factors to the risk of male infertility. Human Reproduction, 16(8), 1768-1776. http://doi.org/10.1093/humrep/16.8.1768

Pasqualotto FF., Sobreiro BP., Hallak J. Pasqualotta, EB. \& Lucan AM. (2006) Cigarette smoking is related to a decrease in semen volume in a population of fertile men. BJU International Journal, 97(2), 324-326. https://doi.org/10.1111/j.1464410X.2005.05906.X

Ramlau Hansen CH., Thulstrup AM., Aggerholm AS., Jensen MS., Toft G. \& Bonde JP. (2006). Is smoking a risk factor for decreased semen quality? A crosssectional analysis. Human Reproduction, 22(1), 188-196. https://doi.org/10.1093/humrep/de1364

Ramlau Hansen CH., Thulstrup AM., Olsen J. \& Bonde JP. (2008). Parental subfacundity and risk of decreased semen quality in te male offspring: a follow- up study. American Journal of Epidemiology, 167(12), 1458-1464 https://doi.org/10.1093/aje/kwn076

Revel A., Raanani H., Younglai E., Xu J., Han R., Savouret JF. and Casper RF. (2001). Resveratrol, a natural aryl hydrocarbon receptor antagonist, protects sperm from DNA damage and apoptosis caused by benzo[a]pyrene. Reproductive Toxicity, 15(5), 479-486. https://doi.org/10.1016/S0890-6238(01)00149-6

Rowe PJ., Comhaire FH., Hargreave TB. \& Mahmoud AMA. (2000). WHO Manual for the Standardized Investigation, Diagnosis and Management of the Infertile Male. Cambridge University Press, Cambridge, UK.

Roychoudhury S., Dorsey C., Choudhury B.P., Kar K.K. (2017) Oxidationreduction potential can help distinguish semen samples under oxidative stress. Hum Reprod 7(32):168.

Roychoudhury S., Massanyi P., Bulla J., Dutta Choudhury M., Lucak N., Filipejova T., Trandzik J.,Toman R. \& Almasiova V. (2010). Cadmium toxicity at low concentration on rabbit spermatozoa spermatozoa motility, morphology and membrane integrity in vitro. Journal of Environmental Science and Health Part A, 45(11),1374-1383. https://doi.org/10.1080/10934529.2010.500909

Roychoudhury S., Sharma R., Sikka S., Agarwal A. (2016). Diagnostic application of total antioxidant capacity in seminal plasma to assess oxidative stress in male factor infertility. J Assist Reprod Genet 33(5),627-635. https://10.1007/s10815-016-0677-5

Saleh RA., Agarwal A., Sharma RK., Nelson DR. \& Thomas AJ. (2002). Effect of cigarette smoking on levels of seminal oxidative stress in infertile men: a prospective study. Fertility and Sterility, 78(3), 491-499. https://doi.org/10.1016/S0015-0282(02)03294-6

Saxena P., Misro MM., Chaki SP., Chopra K., Roy S. \& Nandan D. (2008). Is abnormal sperm function an indicator among couples with recurrent pregnancy loss? Fertility and Sterility, 90(5), 1851858 https://doi.org/10.1016/j.fertnstert.2007.09.031

Sipinen V., Laubenthal J., Baumgartner A., Cemeli E., Linschooten JO., Godschalk RWL., Van Schooten FJ., Anderson D \& Brunborg G. (2010). In vitro evaluation of baseline and induced DNA damage in human sperm exposed to benzo[a]pyrene or its metabolite benzo[a]pyrene-7,8-diol-9,10-epoxide, using the comet assay. Mutagenesis, 25(4), 417-425. doi:10.1093/mutage/geq024

Trummer H., Habermann H., Haas J. \& Pummer K. (2002). The impact of cigarette smoking on human semen parameters and hormones. Human Reproduction, 17(6), 1554-1559. https://doi.org/10.1093/humrep/17.6.1554

World Health Organization. (1999). WHO Laboratory Manual for the Examination of Human Semen and Sperm- Cervical Mucus Interaction, $4^{\text {th }}$ editionCambridge University Press, Cambridge.

World Health Organization. (2010). WHO Laboratory Manual for Examination and Processing of Human Semen, $5^{\text {th }}$ edition.

World Health Organization. (2013). WHO report on Global Tobacco Epidemic Enforcing bans on tobacco advertising, promotion and sponsoring. Accessed on May 2014 at http://www.who.int/tobacco/global_report/2013/en/

Zenzes MT., Beilecki DVM. and Reed TE. (1999). Detection of benzo[a]pyrene diol epoxide-DNA addects in sperm of men exposed to cigarette smoke. Fertility and Sterility, 72(2), 330-335. https://doi.org/10.1093/S0015-0282(99)00230-7 